\title{
BRD4-Interacting Chromatin-Remodeling Complex-Associated Protein
}

National Cancer Institute

\section{Source}

National Cancer Institute. BRD4-Interacting Chromatin-Remodeling Complex-Associated

Protein. NCI Thesaurus. Code C26432.

BRD4-interacting chromatin-remodeling complex-associated protein (1560 aa, 158

$\mathrm{kDa}$ ) is encoded by the human BICRA gene. This protein may play a role in the regulation

of both chromatin remodeling and gene transcription. 